\title{
Limbaga (Proverbs) Simalungun as a Source of Forming Character Education
}

\author{
Asriaty R. Purba ${ }^{1}$, Herlina ${ }^{2}$, Jamorlan Siahaan ${ }^{3}$ \\ ${ }^{1,2,3}$ Faculty of Humanities, Universitas Sumatera Utara, Indonesia \\ asriatyr@gmail.com
}

\section{Abstract}

This research is entitled Limbaga (Proverbs) Simalungun as a Source of Formation of Character Education. Character education is a human activity to establish peace-loving and prosperous personalities in order to build their own personal character and people around them. Character education is closely related to moral education which aims to shape and practice one's ability to perfect him in a better direction. Character education has been applied since childhood. Character education can be done in their family, school and community. The purpose of this study is to describe the character values contained in limbaga (proverbss) that can be used as a source of character education. This research belongs to the category of descriptive qualitative research. The results showed that there were 9 (nine) character values contained in the Simalungun limbaga (proverbs) namely: religious, hard working, honest, disciplined, independent, rewarding achievement, responsibility, social care, and peace-loving.
Keywords

limbaga; Simalungun; character education

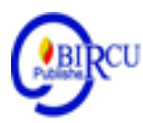

\section{Introduction}

The Indonesian nation consists of various ethnic groups. Each ethnic group has its own oral tradition, oral traditions have many values and norms that should be followed and exemplified in society. Therefore we should be proud and continue to preserve it. In general, oral tradition can be interpreted as a habit in the community that is usually carried out and live in a society whose delivery is conveyed orally from one generation to the next. Oral tradition can be used as a source of local wisdom and can also be used as a source of character building for a nation. As stated by Sibarani (2012: 15) which says that oral tradition can be a cultural power and one of the main sources that is important to identity and building the civilization.

Limbaga (Proverbs) is one of the oral traditions in the Simalungun community. Limbaga (proverbs) Simalungun is an important cultural asset to be preserved considering that limbaga (proverbs) Simalungun can be used as an important source in the formation of character, identity, and civilization. Limbaga (proverbs) Simalungun as a source of local wisdom that contains strong values of goodness and norms that are able to shape the mindset (character) of its speakers. Therefore limbaga (proverbs) must still be maintained and upheld by the local community as a guide in living a social life.

In the past, parents or traditional leaders to convey / give advice to their children or to others often use limbaga (proverbss) which contained of teaching values, good values that can be applied in the community or family environment. According to Gaol (2020) one of the educational reforms includes a view of the existence of students who are integrated with their socio-cultural environment and in turn will foster individuals as individuals and cultured independent members of society. Nowadays the use of limbaga 
(proverbss) has receded along with the disappearance of the older generation and also due to the influence of technological advances that affect people's mindsets. Therefore, the researchers feel interested to investigate Simalungun limbaga (proverbss), considering limbaga (proverbss) as a legacy of many ancestors that save the good values that can be used as forming the character (mindset) of their society.

\section{Review of Literatures}

\subsection{Limbaga (Proverbss)}

Badudu (1983: 111) said that proverbss are expressions / figures of speech that expressed by people with various types of languages. Furthermore Kridalaksana (2008: 189) proverbs is a way of life of a society that has been hereditary used in conversation to give advice, meaning and function through fragments of sentences that have been frozen. In the Indonesian Dictionary (1997: 487) mentioned that proverbss are sentences that arranged beautifully (the language), for example contains of something beautiful for, advice, warnings so as not to forget the goodness and others. From some opinions of above it can be concluded that proverbss are expressions in the form of figures of speech that are delivered indirectly consisting of groups of words or sentences whose structure cannot be changed which contains of advice and that useful of teachings in a society that has been extending from generation to generation.

\subsection{Definition of Character Education}

Etymologically, the word character comes from Latin, that character means character, traits, mentality, personality and character. Character is a picture of behavior in a person's daily habits concerning that it good or bad. In this case, the environment greatly influences the formation of one's character education. This is appropriate with the opinion of Puskur (2010) character is a way of thinking, behaving and acting that is obtained from the character from one's personality as a result of various virtues. Character is the whole values, thoughts, words, and behavior or actions that have shaped of a person (Sibarani, 2012: 138). From some of opinions above it can be concluded that the character is the nature who can tell the difference of someone from other people who are usually obtained from the family environment since childhood and aims to shape one's personality for the better. Character education is a process of education that thoroughly connects the moral dimension with the social environment in the lives of students as the basis for the formation of an independent and quality generation and can also be accounted for accordance with the principle of truth (Raharjo, 2010).

According to T Ramli (2003) character education has the same essence and meaning as moral education. According to Siregar (2020) Personality and character development patterns must be carried out systematically and continuously by involving aspects of knowledge, feelings, and actions. Character education can also be instilled, both in the family, community, and school. The most ideal foundation in character education is the values of faith and piety. Septiadi (2019) states that one of the forms of national character is marked by the formation of the character of its citizens. If people have good character, the nation will also have a good character. Character formation can be taught from an early age through the most basic education, namely nkindergarten (nursery school).

The purpose of character education is explained by Narwanti (2011: 16-17): facilitating the reinforcement and development of certain values so that they are manifested in children's behavior, both during the school process and after the school 
process. Correcting student behavior that is incompatible with the values developed in school, building harmonious connections with families and communities in playing the responsibility of character education together.

\subsection{Theory Used}

The theory used in this study is a theory that refers to the Ministry of National Education (Suyanto, 2011) formulating character values there are eighteen (18 values), as follows: (1) religious, (2) honest, (3) tolerance, (4) discipline, (5) hard work, (6) creative, (7) independent, (8) democratic, (9) curiosity, (10) national spirit, (11) patriotism, (12) respect achievement, (13) friendly / communicative, (14) peace-loving, (15) fond of reading, (16) caring for the environment, (17) caring socially, (18) responsibility.

\section{Research Methods}

The method used in this research is descriptive qualitative method. The purpose of qualitative research is to describe and analyze phenomena, events, social activities, attitudes of beliefs, perceptions, thoughts of people individually or in groups (Moleong, 2007: 7). According to Bogdan and Taylor quoted Ahmad Nizar Rangkuti, in the book Educational Research Methods Quantitative, Qualitative Approach, CAR, and Research Development that qualitative methods as research procedures that produce descriptive data in the form of words or verbal from people and observable behavior. According to Moleong in Angelia (2020), data triangulation is a data checking technique that utilizes something other than the data for checking or comparison purposes. Whereas for data analysis researchers are guided by the interactive technique of Miles and Huberman in Sugiyono (2008) that the activities in qualitative data analysis are carried out interactively and continuously until completion, so that the data is already saturated. Activities in data analysis are data reduction, data display, and conclusion drawing / verification. Qualitative research interpreted by Denzin and Lincoln (2009) is a study that uses natural reasoning, with the intention of interpreting phenomena that occur and is carried out by involving a variety of available methods (descriptive). Descriptive type aims to describe a temporary situation (social settings) running during the study and examine the causes of a particular symptom. This means that the data, facts collected form words or pictures rather than numbers. In other words describe what, why and how an event occurred.Qualitative research is a research procedure that produces descriptive data in the form of written or oral words from people and observable behavior. Descriptive research is research that is intended to investigate the circumstances, conditions or other things that have been mentioned, the results of which are presented in the form of research reports. Descriptive research is the simplest research, compared to other studies, because in this study researchers did nothing about the object or region under study. 


\section{Discussion}

The values of character education contained in limbaga (proverbss) Simalungun are as follows:

Table 1. Values of Character Education in Limbaga (Proverbss) Simalungun

\begin{tabular}{|c|c|c|}
\hline No. & Values of Character & Limbaga (Proverbss) \\
\hline 1. & $\begin{array}{l}\text { Religious } \\
\text { Religious is the community's } \\
\text { belief in the teachings of the } \\
\text { religion that they adopts and } \\
\text { tolerant of the community in their } \\
\text { environment. }\end{array}$ & $\begin{array}{l}\text { Songon salongon bangun-bangun, } \\
\text { isalong roh momburni. } \\
\text { "Like picking leaves bangun-bangun (the } \\
\text { name of vegetable), the more plucked the } \\
\text { more fertile" } \\
\text { The purpose of this limbaga / proverbs is that } \\
\text { we like to give and share our fortune to others. } \\
\text { As the word of God that believed, that } \\
\text { recommend in this life to give to each other, } \\
\text { help each other, because with us giving / } \\
\text { sharing our fortune, God will reciprocate. } \\
\text { This limbaga was usually said by } \\
\text { religious leaders to congregants so the } \\
\text { congregations always give and help each } \\
\text { other, and believe that God will reciprocate } \\
\text { the goodness that has been done. }\end{array}$ \\
\hline 2. & $\begin{array}{l}\text { Hard Work } \\
\text { Hard Work is the act of doing } \\
\text { something ins seriously and } \\
\text { persistently in order to achieve } \\
\text { the maximum results. In other } \\
\text { words do a job as well as } \\
\text { possible. }\end{array}$ & $\begin{array}{l}\text { Halak marsurat buluh, ahu marsurat } \\
\text { hodong. } \\
\text { "Other people write on bamboo, I write on the } \\
\text { midrib" } \\
\text { The purpose of this body of limbaga / } \\
\text { proverbss is to work earnestly, never give up } \\
\text { of the work / task which is being run despite } \\
\text { having many problems or obstacles. } \\
\text { This limbaga was usually said by parents } \\
\text { when advising their children and trust that } \\
\text { their children have to work hard to get what } \\
\text { they want. Because their parents cannot fulfill } \\
\text { the needs of their children, like others. So the } \\
\text { child must be a work harder. }\end{array}$ \\
\hline 3. & $\begin{array}{l}\text { Honest } \\
\text { Honest is not lying. Heartfelt, not } \\
\text { cheating, sincere and can be a } \\
\text { person who is trusted in their } \\
\text { words and actions. }\end{array}$ & $\begin{array}{l}\text { Songon na pabunihon ambasang, } \\
\text { taranggoh hu tanggalopah. } \\
\text { "Like hiding ambacang fruit, it smells to the } \\
\text { next door neighbor". } \\
\text { The purpose of this limbaga / proverbss is } \\
\text { keep telling the truth, because if we lie one } \\
\text { day it will definitely be discovered as well. } \\
\text { Saying the truth can also be pleasing and can } \\
\text { be trusted by the people around us. } \\
\text { This limbaga was usually said by } \\
\text { parents when advising their children that their } \\
\text { children are always honest as the purpose. }\end{array}$ \\
\hline
\end{tabular}




\begin{tabular}{|c|c|c|}
\hline & & $\begin{array}{l}\text { Because how even they keeps a lie, it will } \\
\text { definitely be discovered. Therefore it must be } \\
\text { honest. }\end{array}$ \\
\hline 4. & $\begin{array}{l}\text { Dicipline } \\
\text { Discipline is an act that shows an } \\
\text { obedient of attitude in carrying } \\
\text { out the duties and the obligations. }\end{array}$ & $\begin{array}{l}\text { Adong do aturan ibagas sada-sada } \\
\text { horja, seng ilompoui abara ulu. } \\
\text { "In a job there are rules, the shoulders never } \\
\text { higher than the head ". } \\
\text { The purpose of this limbaga / proverbs is an } \\
\text { attitude / act that is obedient to the rules in } \\
\text { carrying out a task / work. } \\
\text { This limbaga was usually said by } \\
\text { parents when advising their children, that their } \\
\text { children always respect, obey, their superiors } \\
\text { at work or those who are older than them in } \\
\text { carrying out their duties and obligations as the } \\
\text { purpose. }\end{array}$ \\
\hline 5. & $\begin{array}{l}\text { Independet } \\
\text { Independent is the attitude of } \\
\text { someone who can complete his } \\
\text { own work without depending on } \\
\text { others. }\end{array}$ & $\begin{array}{l}\text { Naborit diri gelah, na pa orong-orong. } \\
\text { "Just be sick of yourself, be attacked" } \\
\text { The purpose of this limbaga / proverbs is an } \\
\text { attitude or act that can complete the task / } \\
\text { work by themself, do not expect or depend on } \\
\text { others. } \\
\text { This limbaga was usually said by } \\
\text { parents when advising their children. So their } \\
\text { children have an independent attitude. } \\
\text { Especially if the child is overseas and far away } \\
\text { from parents, the child must be able to solve } \\
\text { their own problems and not depend on others. }\end{array}$ \\
\hline 6. & $\begin{array}{l}\text { Appreciating Achievement } \\
\text { Appreciating achievement is an } \\
\text { attitude or act that shows } \\
\text { appreciation for the success of } \\
\text { others. }\end{array}$ & $\begin{array}{l}\text { Bueian ma ipangan garam, lobeian ma } \\
\text { itangar tahuak ni dayok. } \\
\text { "The more salt eaten, the first heard the sound } \\
\text { of cock crowing ". } \\
\text { The purpose of this limbaga / proverbs is an } \\
\text { attitude / act of respect and wants to learn } \\
\text { from people who have a lot of knowledge and } \\
\text { experience. Usually this is aimed at parents } \\
\text { who have a lot of knowledge and experience. } \\
\text { This limbaga was usually said by } \\
\text { parents when advising their children so that } \\
\text { their children respect those who are older than } \\
\text { them. This is becausethe parents are } \\
\text { considered to have more experience and wiser. }\end{array}$ \\
\hline 7. & $\begin{array}{l}\text { Responsibility } \\
\text { Responsibility is the attitude or } \\
\text { behavior of someone who can } \\
\text { complete the task that has been } \\
\text { carried out both in the family, }\end{array}$ & $\begin{array}{l}\text { Anggo domma itoktok, iporsan ma. } \\
\text { "If it has been cut down, it will be endured ". } \\
\text { The purpose of this limbaga / proverbs is an } \\
\text { attitude of someone that responsible of what } \\
\text { they done. If you have started, you should } \\
\text { finish it well. }\end{array}$ \\
\hline
\end{tabular}




\begin{tabular}{|c|c|c|}
\hline & $\begin{array}{l}\text { community and to the Almighty } \\
\text { God. }\end{array}$ & $\begin{array}{l}\text { This limbaga was usually said by } \\
\text { parents when advising their children so that } \\
\text { their children are responsible for completing } \\
\text { work that has begun. This limbaga is also } \\
\text { commonly said to a pair of brides in the hope } \\
\text { that a head of household must be responsible } \\
\text { to his family. }\end{array}$ \\
\hline 8. & $\begin{array}{l}\text { Social Care } \\
\text { Social care is an attitude that } \\
\text { shows a concern for others who } \\
\text { need help. }\end{array}$ & $\begin{array}{l}\text { Sada sitoktok hitei, ganupan } \\
\text { marujahonsi. } \\
\text { "A person who cuts bamboo / wood to make a } \\
\text { bridge, everyone can use it ". } \\
\text { The purpose of limbaga / proverbs is an } \\
\text { advice so we do not think about ourselves but } \\
\text { rather care for the people around us who need } \\
\text { a help. } \\
\text { This limbaga was usually said by } \\
\text { parents when advising their children, so that } \\
\text { their children will become useful to others, for } \\
\text { example helping others. So their children will } \\
\text { also be appreciated and helped by others later. }\end{array}$ \\
\hline 9. & $\begin{array}{l}\text { Peace Love } \\
\text { Peace love is an attitude or } \\
\text { behavior that wants peace and } \\
\text { avoids conflicts in order to create } \\
\text { a harmonious and a peaceful of } \\
\text { life. }\end{array}$ & $\begin{array}{l}\text { Ulang marsiantukan andalu i bagas } \\
\text { losung, masuk manuk ni halak na bosur. } \\
\text { "Don't pound on each other in a mortar, so } \\
\text { other people's chickens are full". } \\
\text { The purpose of this limbaga / proverbs is } \\
\text { advice to avoid conflicts both of with family } \\
\text { and with others. Always live in harmony and } \\
\text { peace wherever we are. } \\
\text { This limbaga was usually said by } \\
\text { parents when advising their children, to } \\
\text { always make a peace with their siblings, and } \\
\text { avoid the conflict in the family. }\end{array}$ \\
\hline
\end{tabular}

\section{Conclusion}

Based on the results of the research and discussion, there are 9 (nine) character values found in the limbaga / proverbs of Simalungun, namely: (1) Religious; (2) Hard Work; (3) Honestly; (4) Discipline; (5) Mandiri; (6) Appreciating Achievement; (7) Responsibilities; (8) Social Care; and (9) Peace of Love. The character value, can be used as a source of formation of character education for Simalungun society.

1. Remember that Simalungun's limbaga / proverbs has been rarely used, so the hoped is that the younger generation will be more active to learn about it;

2. Proverbs / Limbaga Simalungun contains the value of character building education, therefore, it needs to be included in teaching materials in the study of oral traditions and local wisdom that are useful for young generation.

\section{References}


Angelia, N. et al. (2020). Analysis of Community Institution Empowerment as a Village Government Partner in the Participative Development Process. Budapest International Research and Critics Institute-Journal (BIRCI-Journal) Vol 3 (2): 13521359.

Badudu, J.S.1983. Membina Bahasa Indonesia Baku. Bandung : Pustaka Prima.

Balitbang, Puskur. 2010. Pengembangan Pendidikan Budaya dan Karakter Bangsa. Jakarta : Kemdiknas Balitbang Puskur.

Daryanto. 1997. Kamus Bahasa Indonesia Lengkap. Surabaya : Apollo.

Gaol, R.L., and Sitepu, A. (2020). The Influence of Used Good-Based Learning Media on the Value of Chracter Education and Student's Motivation to Study. Budapest International Research and Critics in Linguistics and Education (BirLE) Journal Vol 3 (4): 1696-1703.

Kridalaksana, Harimurti. 2008. Kamus Linguistik. Jakarta : Gramedia Pustaka Utama.

Moleong, J. Lexy. 2007. Metodologi Penelitian Kualitatif. Bandung : Remaja Rosda Karya.

Raharjo, Sabar Budi. 2010. "Pendidikan Karakter sebagai Upaya Menciptakan Akhlak Mulia" Jurnal Pendidikan dan Kebudayaan, Vol.16,3,229-238.

Rorong, F. D., and Tengker, D. M. 2019. Learning Japanese "Kaiwa" Based on Strategy. Budapest International Research and Critics in Linguistics and Education (BirLE) Journal (2): 594-602.

Siahaan, A., Hafsah, Mandala, S. 2020. The Effect of Scientific Approach and Interpersonal Interaction of Islamic Education to Student Characters in Integrated Islamic School Al Hafiz Langkat District. Budapest International Research and Critics in Linguistics and Education (BirLE) Journal Volume 3, No 3, August 2020, Page: 1281-1286.

Sibarani, Robert. 2012. Kearifan Lokal ; Hakikat, Peran dan metode Tradisi Lisan. Jakarta : Asosiasi Tradisi Lisan (ATL).

Siregar, S. F. Mardianto, Ahkas, A. W. 2020. Extracurricular Implementation of Islamic Education in Character Building Students in MTs EX PGA UNIVA Medan. Budapest International Research and Critics in Linguistics and Education (BirLE) Journal (3): 965-973.

Septiadi, H. N., Andayani, and Wardani, N. E. (2019). Planting Base Value of Hardworking Character Education through Ulid Novel. Budapest International Research and Critics in Linguistics and Education (BirLE) Journal (2): 36-44.

Siahaan, A., Hafsah, Mandala, S. (2020). The Effect of Scientific Approach and Interpersonal Interaction of Islamic Education to Student Characters in Integrated Islamic School Al Hafiz Langkat District. Budapest International Research and Critics in Linguistics and Education (BirLE) Journal Vol 3 (3): 1281-1286.

Siregar, S.F., Mardianto, and Ahkas, A.W. (2020). Extracurricular Implementation of Islamic Education in Character Building Students in MTs EX PGA UNIVA Medan Budapest International Research and Critics in Linguistics and Education (BirLE) Journal Volume 3 (2): 965-973.

Suyanto. 2011. 'Urgensi Pendidikan Karakter" di laman Direktorat Jenderal Manajemen Pendidikan Dasar dan Menengah. (www. educationplanner.org).

Thomas, Lickona. 2012. Character Matters. Jakarta : PT Bumi Aksara.

T. Ramli. 2003. Pendidikan Karakter. Bandung : Angkasa. 